\title{
STUDIES ON THE EFFECT OF PLANT GROWTH REGULATORS ON VEGETATIVE GROWTH, FLOWERING, YIELD AND SHELF LIFE OF THE
}

\author{
MARIGOLD CV. SIRACOLE \\ SWATHI IMANDI ${ }^{1} \&$ G. V. SUBBA REDDY ${ }^{2}$ \\ ${ }^{1}$ Research Scholar, M. S. Swaminathan School of Agriculture Centurion University of Technology \& \\ Management, Parlakhemundi, Odisha, India
}

${ }^{2}$ Scientist Horticulture BCT-Krishi Vigyan Kendra, Haripuram, Visakhapatnam District, Andhra Pradesh, India

\begin{abstract}
The present experiment entitled "Effect of plant growth regulators on vegetative growth, flowering, yield and shelf life of the Marigold cv. Siracole" was carried out during 2016-2017 at BCT Krishi Vigyan Kendram, Haripuram, Visakhapatnam district. The experiment was designed to study the effect of plant growth regulators namely $\mathrm{GA}_{3}$ at 50 ppm, 100 ppm, 150 ppm and NAA at 150 ppm, 200 ppm, 250 ppm on vegetative growth, flowering, yield, and shelf life of marigold with 7 treatments in three replications in a randomized block design. The treatment GA 150 ppm recorded maximum values for plant height $(50.71 \mathrm{~cm}, 74.57 \mathrm{~cm})$, number of branches $(15.59,19.45)$ over other treatments after 60 and 90 days after transplanting. Control resulted in the minimum number of branches per plant (10.4,13.3), plant height (46.6cm, 58.5 cm) over other treatments. Among the floral parameters, minimum number of days to first floret appear (44.25days), and 50 percent flowering (58.37days), number of flowers per plant (72.81), flower size (21.58 cm), flower weight (10.7 g), flower yield per plant (524.6 g), per hectare (26.33MT) and shelf life (3.55days) was recorded with GA 150 ppm. Minimum flower size $(19.6 \mathrm{~cm})$ and minimum flower weight $(7.3 \mathrm{~g})$, maximum number of days to first floret appear (53.18 days), maximum 50 percent flowering (71.3 days), minimum number of flowers per plant (29.49), minimum flower yield per plant (335.3 g), per hectare (16.6 MT) and shelf life (3.1days) was recorded with control. GA3 100 ppm (46.41 days) and NAA 250 ppm (46.48) are on par with each other at first flower initiation. It was found that $\mathrm{GA}_{3}$ at 150 ppm was recorded better results for growth, flowering, yield and shelf life of marigold cv. Siracole.

KEYWORDS: Marigold, Growth Promoters, Ga3, NAA \& Plant Hormones
\end{abstract}

Received: May 02, 2017; Accepted: May 27, 2017; Published: Jun 28, 2017; Paper Id.: IJASRAUG20179

\section{INTRODUCTION}

Marigold (TageteserectaL.) is an important commercial loose flower in India that belongs to the family Asteraceae (Compositae). Marigold is commonly used for garland making in India because of its ease in cultivation, adaptability to varying soil and climatic conditions. It has a long duration of flowering so it is an economic produce as compared to other costly flowers. Although the origin of marigold T. erectais Mexico, it is presumed to be of Indian origin, due to its adaptability, popularity and wide cultivation in India (Desai, 1967). Marigold flowers are traditionally used for offering in temple, churches and used in the festival for beautification of the landscape. It is highly suitable for making flower beds in herbaceous borders and also found ideal for newly planted shrubberies to provide color and fill the gap in the landscape. Marigold, not only cultivated as an ornamental cut flower and landscape plant, but also a source of carotenoid pigment for poultry feed to intensify the yellow color of egg yolks and 
broiler skin. Apart from the poultry industry, marigold dye is also used in the textile industry (HemlaNaiket al., 2004). The uses of marigold are many fold, often referred to as, "Versatile crop with golden harvest". Marigolds produce thiopenes, which are toxic to nematodes and used as a trap crop in tomato, brinjal, tobacco etc. (Raghava, 2000).

The principal pigment in the flower is xanthophylls particularly lutein which accounts for more than $80-90 \%$ and is present in the form of esters of palmitic and myristic acid. Hence, there is great demand for natural colors of marigold in the international market. In India, the extraction of carotenoids on a commercial scale is being done in Kerala and Andhra Pradesh states, particularly in Cochin and Hyderabad respectively, and it is being exported to Mexico (Raghava, 2000). Growth regulators are defined as chemical substances which are produced naturally in plants and are capable of translocation, regulating one or more physiological reaction when present in low concentration and they have been used in floriculture to manipulate plant growth in a desired direction (Sharma et al., 2001). Naphthalene acetic acid (NAA) inhibits the shoot length and promotes the root length and is reported to be a rooting promoter improves plant growth (Ullahet al, 2013). Gibberrellic acid (GA3) application to the shoot enhances both shoot and root elongation. Gibberellic acid increased to be very effective in manipulating growth and flowering in marigold (Kumar et al., 2014). The experiment was carried out to assess the optimum concentration of various growth regulators to cause a beneficial effect on growth, flowering, yield and shelf life of marigold (TageteserectaLinn.) CV. Siracole.

\section{MATERIALS AND METHODS}

The experiment was conducted at BCT-Krishi Vigyan Kendra, Haripuram Visakhapatnam district. The experiment site is located at altitude of $73 \mathrm{~m}$ above mean sea level with a geographical bearing of $18^{0} 7^{\prime}$ North latitude and $83^{\circ} 25^{\prime}$ east longitude comes under North coastal Andhra Pradesh. The experiment was designed to study the effect of plant growth regulators namely $\mathrm{GA}_{3}$ at $50 \mathrm{ppm}, 100 \mathrm{ppm}, 150 \mathrm{ppm}$ and NAA at $150 \mathrm{ppm}, 200 \mathrm{ppm}, 250$ ppm on vegetative growth, flowering, yield, and shelf life of marigold with 7 treatments in three replications in a randomized block design. Thirty days old healthy uniform seedlings were transplanted in the experimental plots. Immediately after transplanting, a light irrigation was given to crop for better establishment of seedlings in the main field. Calculated quantity of GA3 and NAA was dissolved in ethyl alcohol separately for each concentration in $10 \mathrm{ml}$ test tube and then the volume was made up to one liter with distilled water. The prepared solutions were sprayed immediately after preparation. For recording biometric observations, five plants per plot were selected at random and labeled. The data pertaining to various parameters were subjected to statistical analysis following the method of analysis of variance for randomized block design as per Panse and Sukhatme (1978).

\section{RESULTS AND DISCUSSIONS}

The results pertaining to plant height at 30 days after transplanting is not significantly different. The plant height was significantly influenced by plant growth regulators at 60 days after transplanting. Among the plant growth regulators, maximum plant height was recorded with $\mathrm{GA}_{3}$ at $150 \mathrm{ppm}(60.50 \mathrm{~cm})$ followed by NAAat $250 \mathrm{ppm}(55.70 \mathrm{~cm}), \mathrm{GA}_{3}$ at 100 ppm $(52.62 \mathrm{~cm}), \mathrm{GA}_{3}$ at $50 \mathrm{ppm}(50.71 \mathrm{~cm})$, NAA at150 ppm $(48.53 \mathrm{~cm})$, NAA at $200 \mathrm{ppm}(47.43 \mathrm{~cm})$ and they differed significantly. Minimum plant height was recorded with control (T7) (46.66cm). Plant height at 90 days after transplanting was significantly differed with plant growth regulators and maximum plant height was recorded with GA 3 150ppm (74.57), followed by NAA 250ppm (71.62cm), GA 100 ppm (70.84cm), GA 50 ppm (70.32cm), NAA 200 ppm (68.39cm), NAA 150 ppm $(64.70 \mathrm{~cm})$. Minimum plant height was recorded with control $(58.56 \mathrm{~cm})$. Among the plant growth regulators studied, maximum number of branches were recorded with $\mathrm{GA}_{3}$ 150ppm (15.59) followed by NAA 250ppm (14.39) GA 100 ppm (13.80), $\mathrm{GA}_{3} 50$ ppm (12.63), NAA, 200 ppm (11.63), NAA 150 ppm (11.52) and they differed significantly except NAA 
$150 \mathrm{ppm}$ and $200 \mathrm{ppm}$. Minimum numbers of branches were recorded with control $\left(\mathrm{T}_{7}\right)(10.49)$. Significant differences were also observed in a number of branches per plant at 90 DAP due to plant growth regulators studied. Maximum number of branches were recorded with $\mathrm{GA}_{3} 150 \mathrm{ppm}$ (19.45) followed by NAA250ppm (18.63), GA $100 \mathrm{ppm}$ (17.62), GA $50 \mathrm{ppm}$ (16.34), NAA, $200 \mathrm{ppm}$ (15.72), NAA $150 \mathrm{ppm}$ (14.42) and they differed significantly. Minimum number of branches were recorded with control $\left(\mathrm{T}_{7}\right)$ (13.35). The treatment GA3 at $150 \mathrm{ppm}$ recorded maximum plant height when compared to other treatments might be due to enhanced cell division, cell enlargement, increased plasticity of cell, promotion of protein synthesis coupled with higher apical dominance (Suryalaksgmipaleiet al., 2016), Doddagoudaret al. (2004) and Himabindu (2010) in marigold. Padma Priya and Chezhiyan (2003) reported that maximum plant height was obtained with GA3 on chrysanthemum (Dendranthemagrandiflora) due to the mechanism involving the conversion of starch to sugar was inferred by analogy with known effects of GA3 which increases plant height. The increase of plant height by GA3 was reported earlier by Girwaniet al. (1990) in African marigold, Application of $\mathrm{Ga}_{3}$ increased the plant height, no. of branches in marigold (Suryalakshmipaleiet al., 2016).

The data recorded in marigold on the number of days taken to first flower bud initiation due to plant growth regulators indicated that GA3 $150 \mathrm{ppm}$ (44.25 days) recorded a minimum number of days to first flower bud initiation followed by GA3 100 ppm (46.41days), NAA, 250 ppm (46.48 days) GA 100 ppm (46.41 days), GA 50 ppm (47.37 days), NAA $200 \mathrm{ppm}$ (48.41days), NAA $150 \mathrm{ppm}$ (48.39 days). GA3 $100 \mathrm{ppm}$ and NAA $250 \mathrm{ppm}$ are on par with each other. Maximum number of days to first flower bud initiation was recorded with control (T7) (53.18 days). Early initiation of flowering with $\mathrm{GA}_{3}$ application might be due to the early production of florigine in $\mathrm{GA}_{3}$ treated plants, as $\mathrm{GA}_{3}$ is a component of florigine which is involved in flower initiation in plant system. Deotaleet al. (1994) reported that $\mathrm{GA}_{3} 150 \mathrm{ppm}$ hastened flower bud initiation and opening of flowers in Chrysanthemum due to the synergistic action of GA3 with IAA. Muthukumaret al. (2012) reported that GA3 treatment increased photosynthesis, respiration along with enhanced CO2fixation that led to early flowering in Chrysanthemum. Minimum number of days to 50\% flowering was recorded with GA3 150 ppm (58.37 days) and followed by GA3 100 ppm (60.31 days), GA 50 ppm (61.26 days), NAA, 250 ppm (63.48 days), NAA 200 ppm (64.48 days), NAA 150 ppm (65.37 days) and they differed significantly in marigold. Maximum number of days to $50 \%$ flowering was recorded with control (T7) (71.32 days). The data recorded on a number of flowers per plant as influenced by plant growth regulators indicated that GA3 150ppm recorded maximum number of flowers per plant (72.817) followed by NAA $250 \mathrm{ppm}$ (70.193), GA3 100 ppm (68.79), GA 50 ppm (64.72), NAA 150 ppm (61.480), NAA 200 ppm (59.460) and they differed significantly. Minimum number of flowers were recorded in the control (46.59). Number of flowers per plant were maximum in all concentrations of GA3, NAA over control. GA3 in all the concentrations recorded the maximum number of flowers per plant than NAA. The treatment control recorded the lowest number of flowers per plant than the growth regulator treatments studied. The data on flower weight as influenced by plant growth regulators revealed that maximum flower weight was recorded with $\mathrm{GA}_{3} 150 \mathrm{ppm}(10.70 \mathrm{~g})$ followed by NAA $250 \mathrm{ppm}(8.56 \mathrm{~g})$ and $\mathrm{GA}_{3} 100 \mathrm{ppm}(8.51 \mathrm{~g}), \mathrm{GA}_{3} 50 \mathrm{ppm}(7.57 \mathrm{~g})$, NAA $200 \mathrm{ppm}(7.61 \mathrm{~g})$, NAA $150 \mathrm{ppm}(7.57 \mathrm{~g})$ and they differed significantly. The plant growth regulators NAA at $250 \mathrm{ppm}$ and $\mathrm{GA}_{3}$ at $100 \mathrm{ppm}$ are on par. Minimum flower weight was recorded with control (T7) (7.363). Increase in weight of individual flower due to $\mathrm{GA}_{3}$ application was reported by KishanSwaroopet al. (2007) and Dishapatilet al. (2016) in marigold, Sharma et al. (2001), Gautamet al. (2006) in Chrysanthemum and Himabindu (2010) in African marigold cv. Pusa Narangi Gainda. According to Suryalakshmiet al., (2016) early bud initiation, more no. of flowers and maximum flower weight was recorded in application of $\mathrm{Ga}_{3}$ in marigold. 
Table 1: Studies on the Effect of Growth Regulators on Vegetative Parameters in Marigold Cv. Siracole

\begin{tabular}{|c|c|c|c|c|c|c|}
\hline \multirow{2}{*}{ Treatments } & \multicolumn{3}{|c|}{ Plant Height } & \multicolumn{3}{|c|}{ No. of Branches } \\
\hline & 30 days & 60 days & 90 days & 30 days & 60 days & 90 days \\
\hline $\mathbf{T}_{1:} \mathrm{GA}_{3} 50 \mathrm{ppm}$ & 22.500 & 50.710 & 70.323 & 8.403 & 12.633 & 16.343 \\
\hline $\mathbf{T}_{2:} \mathrm{GA}_{3}: 100 \mathrm{ppm}$ & 24.577 & 52.627 & 70.847 & 9.540 & 13.800 & 17.627 \\
\hline $\mathbf{T}_{3:} \mathrm{GA}_{3}: 150 \mathrm{ppm}$ & 27.617 & 60.503 & 74.573 & 11.613 & 15.597 & 19.457 \\
\hline $\mathbf{T}_{4:}$ NAA:150 ppm & 22.820 & 48.537 & 64.700 & 7.647 & 11.527 & 14.420 \\
\hline $\mathbf{T}_{5:}$ NAA:200 ppm & 21.527 & 47.433 & 68.390 & 8.363 & 11.630 & 15.720 \\
\hline $\mathbf{T}_{\mathbf{6}}$ NAA:250 ppm & 25.857 & 55.703 & 71.623 & 10.330 & 14.393 & 18.637 \\
\hline $\mathbf{T}_{7:}$ Control & 19.610 & 46.667 & 58.560 & 7.533 & 10.493 & 13.357 \\
\hline CV value & 7.04 & 8.49 & 11.18 & 8.37 & 11.96 & 9.29 \\
\hline CD (0.05) & 0.43 & 0.45 & 0.22 & 0.54 & 0.45 & 0.37 \\
\hline
\end{tabular}

Among the plant growth regulators studied, $\mathrm{GA}_{3}$ at $150 \mathrm{ppm}$ recorded maximum flower size $(21.586 \mathrm{~cm})$ followed by $\mathrm{GA}_{3} 100$ ppm (19.857cm), GA 50 ppm (19.694), NAA 250 ppm (18.701). NAA 200 ppm (18.642), NAA, 150 ppm (17.795) and they were significant. The treatments $\mathrm{GA}_{3} 50 \mathrm{ppm}$ and $100 \mathrm{ppm}$ were on par with each other and NAA 200ppm and 250 ppm are on par with each other on flower size. Minimum flower size was recorded with control $(\mathrm{T} 7)(15.631 \mathrm{~cm})$. GA 3 and NAA at all concentrations recorded highest flower size over control Girwaniet al. (1990) reported that GA 3 induced maximum flower size in African marigold. Increase in the diameter of individual flower due to GA3 application was reported by Kishan Swaroopet al. (2007) in marigold. Sharma et al. (2001), Gautamet al. (2006) in Chrysanthemum and Himabindu (2010) in African marigold cv. Pusa Narangi Gainda. Among the plant growth regulators, $\mathrm{GA}_{3}$ recorded maximum flower yield per plant (524.66gm) followed by NAA (506.33 gm). On perusal of data on flower yield per hectare as influenced by plant growth regulators at different concentrations revealed that, $\mathrm{GA}_{3} 150 \mathrm{ppm}$ recorded maximum flower yield per plant (524.66 gm ) followed by NAA 250 ppm (506.33gm) GA 100 ppm (489.66 gm),GA 50 ppm (473.33 gm), NAA 150 ppm (448.66 gm), NAA 200 ppm (431.0 gm). Minimum flower yield per plant was recorded with control (335.33 gm). GA 3 and NAA at all concentrations recorded highest flower yield per plant over control Maximum flower yield per hectare was recorded with GA 3 (28.33MT) followed by NAA (26.28MT) among the plant growth regulators studied On perusal of data on flower yield per hectare as influenced by plant growth regulators at different concentrations revealed that, $\mathrm{GA}_{3} 150$ ppm recorded maximum flower yield per hectare (28.33MT) followed by NAA 250 ppm (26.28MT), GA 100 ppm (25.79 MT),GA 50 ppm (24.62 MT), NAA 150 ppm (22.42 MT), NAA 200 ppm (21.41 MT). GA 3 and NAA at all concentrations recorded highest flower yield per hectare over control (16.63MT). Among the plant growth regulators, $\mathrm{GA}_{3}$ recorded maximum shelf life (3.557 days) followed by NAA (3.117 days). On perusal of data

Table 2: Studies on the Effect of Plant Growth Regulators on Floral and Yield Parameters of Marigold Cv. Siracole

\begin{tabular}{|c|c|c|c|c|c|c|c|c|}
\hline Treatments & $\begin{array}{l}\text { No. of Days } \\
\text { Taken for } \\
\mathbf{1}^{\text {st }} \text { Flower } \\
\text { Initiation }\end{array}$ & $\begin{array}{c}\text { No. of Days } \\
\text { Taken for } \\
50 \% \\
\text { Flowering }\end{array}$ & $\begin{array}{c}\text { No. of } \\
\text { Flowers/Plant }\end{array}$ & $\begin{array}{c}\text { Weight of } \\
\text { Flower } \\
\text { (gm) }\end{array}$ & $\begin{array}{c}\text { Size of } \\
\text { Flower }(\mathrm{cm})\end{array}$ & $\begin{array}{c}\text { Yield } \\
\text { (gms) / } \\
\text { plant }\end{array}$ & $\begin{array}{c}\text { Yield } \\
\text { (MT)/ } \\
\text { ha }\end{array}$ & $\begin{array}{c}\text { Shelf } \\
\text { Life of } \\
\text { Flowers } \\
\text { (Days) }\end{array}$ \\
\hline $\mathbf{T}_{\mathbf{1}:} \mathrm{GA}_{3} 50 \mathrm{ppm}$ & 47.37 & 61.26 & 64.72 & 7.57 & 19.69 & 473.3 & 23.62 & 2.65 \\
\hline $\mathbf{T}_{\mathbf{2}:} \mathrm{GA}_{3}: 100 \mathrm{ppm}$ & 46.41 & 60.31 & 68.79 & 8.51 & 19.85 & 489.6 & 24.79 & 3.22 \\
\hline $\mathbf{T}_{\mathbf{3}:} \mathrm{GA}_{3}: 150 \mathrm{ppm}$ & 44.25 & 58.37 & 72.81 & 10.70 & 21.58 & 524.6 & 26.33 & 3.55 \\
\hline $\mathbf{T}_{4}:$ NAA: $150 \mathrm{ppm}$ & 48.39 & 65.37 & 61.48 & 7.57 & 17.79 & 448.6 & 22.42 & 2.43 \\
\hline $\mathbf{T}_{5:}$ NAA:200 ppm & 48.41 & 64.48 & 59.46 & 7.61 & 18.64 & 431.0 & 21.47 & 2.74 \\
\hline $\mathbf{T}_{6}:$ NAA: $250 \mathrm{ppm}$ & 46.48 & 63.48 & 70.19 & 8.56 & 18.70 & 506.3 & 25.28 & 3.11 \\
\hline $\mathbf{T}_{7: \text { Control }}$ & 53.18 & 71.32 & 46.59 & 7.36 & 15.63 & 335.3 & 16.63 & 2.41 \\
\hline $\mathrm{CV}$ value & 6.43 & 7.30 & 8.02 & 7.04 & 8.91 & 11.06 & 9.98 & 5.73 \\
\hline $\mathrm{CD}(0.05)$ & 0.36 & 0.34 & 1.16 & 0.44 & 0.30 & 8.816 & 0.40 & 0.29 \\
\hline
\end{tabular}


On shelf life of marigold as influenced by plant growth regulators at different concentrations revealed that, $\mathrm{GA}_{3} 150$ ppm recorded maximum shelf life (3.557 days) followed by $\mathrm{GA}_{3} 100$ ppm (3.227 days), NAA 250ppm (3.117 days), NAA 200 ppm (2.740 days). $\mathrm{GA}_{3} 50 \mathrm{ppm}$ (2.650 days), NAA $150 \mathrm{ppm}$ (22.42 MT), Both $\mathrm{GA}_{3} 100 \mathrm{ppm}$ and NAA 250ppm are on par with each other. $\mathrm{GA}_{3}$ and NAA at all concentrations recorded highest flower yield per hectare over control (2.413 days). Delvadiaet al. (2009) revealed that maximum shelf-life were observed with single spray of $150 \mathrm{ppm} \mathrm{GA}_{3}$. Kiran Kumar et al. (2011) stated thatGA3 at $200 \mathrm{ppm}$ application enhanced the duration of flower vase life (22.88 days) in china aster. Muthu Kumaret al. (2012) observed that gibberellic acid at $100 \mathrm{ppm}$ level drastically increased the vase life (2.6 days). Harithanaiduet al., (2014) reported that application of $\mathrm{Ga}_{3}$ at higher concentrations increased the shelf life of the marigold.

\section{REFERENCES}

1. Delvadia D. V., Ahlawat T. R. and Meena B. J. 2009. Effect of different ga3 concentration and frequency on growth, flowering and yield in gaillardia (Gaillardia pulchellafoug.) Cv. LorenzianaJ. Hortl. Sci. Vol. 4 (1): 81-84

2. DeotaleA B Belorkar P V Patil S R Zode V N and Keche M B 1994 Effect of date of planting and foliar spray of GA3 on flowering and yield of Chrysanthemum. Journal of soils and crops 4(2): 148-151.

3. DishaPatil, NehaChopde, SushmaLokhande and M. H. Bhande 2016 Studies on response of african marigold to plant growth regulators for seed production Plant Archives Vol. 16: 423-425.

4. Doddagoudar S R Vyakarnahal B S and Shekar gouda M 2004 Effect of mother plant nutrition and chemical spray on seed germination and seedling vigour of China aster cv. Kamini Karnataka journal of agriculture sciences 17 (4)701-704.

5. DuttaSeemanthini J P Ramdas and Md Abdul khader 1993 Regulation of flowering by growth regulators in (chrysanthemum indicumLin) Cv. Co1. South Indian Horticulture 41(5):293-299.

6. Gautam S K Sen N L Jain M C and Dashora L. K 2006 Effect of plant growth regulators on growth, flowering and yield of chrysanthemum (Chrysanthemum morifoliumRam.) cv. Nilima. The Orissa Journal of Horticulture 34 (1): 36-40.

7. Girwani A SrihariBabu R and Chandrasekhar R 1990 Response of marigold (Tageteserecta) to growth regulators and zinc. Indian journal of Agricultural sciences 60(3): 220-222.

8. Haritha Naidu J, Ashok P, Chandra Sekhar R AndSasikala K. 2014 Effect of plant growth retardants and spacings on vegetative growth and flower yield of African marigold (TageteserectaL) cv PusaNarangiGaindaInternational Journal of Farm Sciences 4(2): 92-99, 2014.

9. HemlaNaik B PatilA APatil V S Basavaraj N Heremath S M 2004 Effect of pinching and chemicals on xanthophyll yield in African marigold (TageteserectaL.) Journal of Ornamental Horticulture 7 (3-4): 182-190.

10. Kirankumar E. 2011studies on the effect of plant growth regulators on growth, flower yield and vase life of China aster (Callistephuschinensis(l.) ness) CV. Kamini in coastal districts of Andhra pradesh.thesis submitted to the Andhra pradesh horticultural university.

11. Kishan Swaroop Kanwar P Singh Raju D V S 2007 Vegetative growth, flowering and seed characters of African marigold( Tageteserecta Linn.) as influenced by different growth substances during mild off seasons. Journal of Ornamental Horticulture10 (4): $268-270$.

12. Kumar M., Singh, A. K. and Kumar A. 2014. Effect of plant growth regulators on flowering

13. of Yield attributes African marigold (tageteserectal.) Cvpusanarangigainda. Plant Archives, 14 (1), 363-365.

14. Mithilesh Kumar, A. K. Singh and Ashok Kumar 2014 Effect of plant growth regulators on flowering and yield attributes of african 
marigold (Tageteserectal.) CvPusanarangigainda

15. Plant Archives Vol. 14 (1):363-365.

16. Muthu Kumar S., Ponnuswami V., Jawaharlal M. And Ramesh Kumar A. 2012. Effect of plant growth regulators on growth, yield and exportable quality of cut roses The bioscan an international quarterly journal of life sciences 7(4): 733-738.

17. Padma priya S and Chezhiyan 2003 Effect of certain growth substances on morphological characters and yield of Chrysanthemum (Dendranthemagrandifloratzelvev) cultivars. South Indian Horticulture 51 (1-6): 60-65.

18. Ravi HimaBindu 2010 M.Sc Thesis Submitted to Andhra Pradesh Horticultural University, Venkataramannagudem, West Godavari.

19. Raghava S P S 2000 Marigold versatile crop with golden harvest. Floriculture Today 4 (11): 40-41.

20. Sharma C. P., Maurya A. N., Srivastava O. P. and Ashok Mishra 2001. Role of GA3, Malic hydrazide and Ethrel in modifying vegetative and floral characters of Chrysanthemum morifoliumRam. The Orissa Journal of Horticulture 29(2):35-38.

Suvalaxmi Palei A. K. Das D. K. Dash 2016 Effect of plant growth regulators on growth, flowering and yield attributes of african marigold (Tageteserecta l.) Research Paper Agriculture E-ISSN No: 2454-9916 Vol 6 (2).

22. Zia Ullah Sayed Jaffarabbas Nisar Naeem Ghosia Lutfullah Taimur Malik, Malik AtiqUllah Khan and Imran Khan 2013 African Journal of Agricultural Research Effect of indolebutyric acid (IBA) and naphthaleneacetic acid (NAA) plant growth regulators on Mari gold (TageteserectaL.) Vol. 8(29), pp. 4015-4019. 